\title{
CHANGES OF POTENTIALLY ANTI-NUTRITIVE COMPONENTS IN HUNGARIAN POTATOES FROM ORGANIC AND CONVENTIONAL FARMING
}

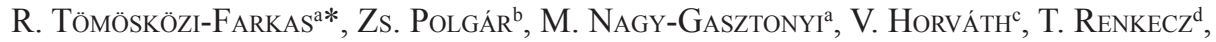 \\ K. SimON ${ }^{d}$, F. BOROSS ${ }^{\mathrm{a}}$, Z. FABULYA ${ }^{\mathrm{e}}$ and H. DAOOD ${ }^{\mathrm{a}}$ \\ ${ }^{a}$ Central Food Research Institute, Budapest H-1022, Herman Ottó út 15. Hungary \\ ${ }^{b}$ University of Pannonia, Potato Research Centre, H-8360 Keszthely, Deák F. u. 16. Hungary \\ ${ }^{c}$ MTA-BME Research Group for Technical Analytical Chemistry, H-1111 Budapest, Szt. Gellért tér 4. Hungary \\ ${ }^{\mathrm{d} B u d a p e s t}$ University of Technology and Economics, Faculty of Chemical Technology and Biotechnology, \\ Department of Inorganic and Analytical Chemistry, H-1111 Budapest, Szt. Gellért tér 4. Hungary \\ ${ }^{\text {e}}$ University of Szeged, Department of Engineering., H-6720 Szeged, Dóm tér 12. Hungary
}

(Received: 6 August 2013; accepted: 13 October 2013)

\begin{abstract}
Anti-nutritive components in multi resistant potato cultivars were investigated in relation to conventional and organic farming for three years. Glycoalkaloids, nitrate, nitrite, asparagine, and glutamine contents of tubers were examined. Farming technology was found not to have an effect on the level of glycoalkaloids, which was influenced mostly by the genotype and season. Nitrogen fertilisation caused significant increase in nitrate, asparagine, and glutamine contents as compared to organic farming. Nitrite content was found to be more independent of farming technologies than nitrate. Tubers of cultivar Rioja had the lowest nitrate content irrespective of season or technology. In conclusion, the absolute amount and changes of different anti-nutritive components of potato tubers were influenced differently by the technology, genotype, and season in a complex manner. Organic farming had no effect on the glycoalkaloid content, but the nitrate levels had a tendency to be lower compared to conventional farming. This can be seen as a positive effect of organic farming.
\end{abstract}

Keywords: organic farming, potato, glycoalkaloids, nitrate, asparagine, glutamine

Organic farming extends rapidly, because crop production without or with limited use of fertilizers and pesticides is beneficial to the consumers and the environment as well. Though numerous researches have been conducted during the last decades to compare organic and conventional foods with respect to nutritional composition, the effects of organic farming on vegetable crop quality and nutrient content are still not consistent. Some studies concluded that vegetables originated from organic production are richer in nutrients, particularly organic acids, vitamins, and polyphenols, than conventionally produced ones (WINTER \& DAVIS, 2006). Other studies could not confirm significant differences in nutrients between organic and conventional production methods (WARMAN \& HAVARD, 1998).

Two major hypotheses have been suggested to explain the possible increases in secondary metabolites in organic versus conventional foods. According to the first hypothesis in conventional agriculture synthetic fertilizers make $\mathrm{N}$ more available for the plants and may accelerate plant growth and development. This rapid growth results in a decrease in the production of plant secondary metabolites. The second hypothesis considers the chemical

\footnotetext{
* To whom correspondence should be addressed.

Phone: +36(1)214 1249; fax:+36(1)214 1249; e-mail: r.farkas@cfri.hu
} 
defence mechanisms of plants to stressful environment (AsAmi et al., 2003). The same mechanisms may result in the elevation of metabolites having both toxic and positive nutritional effects (WINTER \& DAVIS, 2006).

Potato is one of the most important staple foods and it plays a significant role in human diet worldwide. Its intensive cultivation assumes the operation of effective plant nutrition and plant protection systems. In most cases this means the intensive use of chemicals leading to serious environmental and food safety concerns. Growing of potato under organic conditions to overcome such problems can be a solution. However, organic potato producers face difficulties in terms of dealing with adequate plant nutrients, especially nitrogen application, also weed, insect, and disease control issues (HAJsLova et al., 2005; Herencia et al., 2011). The use of cultivars having a wide range of adaptability to different factors is a prerequisite for successful organic potato production.

From the human nutrition point of view, occurrence of several types of glycoalkaloids threatens consumers' health (FRIEDMAN \& LEvin, 2009). The total glycoalkaloid (TGA) content in tubers is affected by the genotype, climate, production technology, storage time, sprouting, and exposure to light and heat. Results of researchers did not prove a definite effect on the formation of glycoalkaloids in tubers. Some of them did not reveal any differences between organic and integrated farming methods, others found the TGA content higher or lower in organic plants (ABREU et al., 2007).

Acrylamide (AA) is a well known hazardous component of foods with neurotoxic, carcinogenic effects. The major route for AA formation is the thermal degradation of free asparagine in the presence of reducing sugars during the Maillard reaction. Potato tubers contain substantial amounts of the AA precursors, which explains the high concentrations of acrylamide in potato products. Reducing sugars are regarded as limiting factors with respect to acrylamide formation, thus maintaining low sugar content in tubers is crucial. However, reducing sugars can accumulate rapidly in tubers stored at temperatures below $5{ }^{\circ} \mathrm{C}$ and increase to a point where reducing sugar content is no longer limiting and asparagine content becomes the critical driving factor (MATSURRA-Endo et al., 2006). This was the reason to investigate also the glutamine and asparagine content in potato tubers.

Consumption of high levels of nitrate may cause health problems, (methemoglobinemia and cancer), especially in babies. Several scientists concluded that the nitrate content of organically grown foodstuffs (including potato) is generally lower than in conventionally grown products (RUTKOwSKA, 1999).

The objective of the present study was the comparison of internal components of three Hungarian potato cultivars having complex resistance traits due to their wild species origin, grown under conventional and organic farming practices with special focus on the measurement of TGA, nitrate, nitrite, asparagine, and glutamine content of tubers. The study of seasonal effect (3 years) on such anti-nutritive compounds was also aimed at.

\section{Materials and methods}

\subsection{Chemicals}

The standards materials were purchased from Sigma-Aldrich Ltd. (St Louis, USA). Acetonitrile, acetic acid, potassium hexacyanoferrate(II), zinc acetate, sulphanilamide chloride and N-(1-naphtyl) ethylenediamine were purchased from Merck (Darmstadt, Germany). Acids used for sample digestion were of Hiperpur grade from Panreac (Darmstadt, 
Germany). Standard solutions for elemental analysis were purchased from Carlo Erba (Paris, France), Merck, and Panreac. All reagents were of analytical reagent grade. Ultrapure water generated by the Milli-Q System (Millipore, Darmstadt, Germany) was used. SPE cartridge $($ ENVI-18 $6 \mathrm{ml})$ and PTFE sample filter $(25 \mathrm{~mm} \times 0,45 \mu \mathrm{m})$ were purchased from SUPELCO Co. (St Louis, USA).

\subsection{Plant material and growth conditions}

Potato cultivars Rioja, Hópehely, and White Lady originate from the commercial breeding programme of the University of Pannonia, Potato Research Centre, Keszthely, Hungary. The cultivars show complex resistance to potato virus $\mathrm{Y}, \mathrm{X}$, and A, leaf roll virus (PVY, PVX, PVA, and PLRV), and also to common scab (Streptomyces scabies). CV. Hópehely and White Lady are resistant to potato golden cyst nematode (Globodera rostochiensis, pathotype Ro1 and Ro4), while White Lady has high field resistance to potato late blight (Phytophthora infestans). During their breeding, exotic potato species S. acaule, S. demissum, S. stoloniferum, $S$. vernei, and $S$. tuberosum ssp. andigenum were used as sources of resistance genes. The cultivars were cultivated under conventional and organic farming conditions at Keszthely and Rábcakapi, Hungary in four replications, where 56 plants represented one replicate in 2007-2009. Organic farming conditions, applied plant nutrition and plant protection, were certified by Biokontroll Hungária Nonprofit Ltd. Soil parameters were determined by official soil sampling and measurements. No irrigation was applied at any location and any of the years. Applied plant protection technologies allowed healthy plant development till natural maturing.

\subsection{Sampling}

After harvest, $20 \mathrm{~kg}$ of tubers from each experimental parcel representing the farming technologies were collected. For the 3 parallel measurements $3 \times 3$ tubers were selected and prepared to get homogenous samples.

\subsection{Potato processing}

Potatoes were washed, peeled ( $2 \mathrm{~mm}$ thickness) according to the food processing technology, and crushed by chopper (Philips HR 1392). All analyses were carried out with peeled raw materials but for the comparison of the farming systems this sample preparation is adequate. All samples were then freeze dried and subjected to further analysis. The lyophilised samples were ground to powder (Bosch MKM6003) and were stored at room temperature. The investigated components are stable at room temperature and our preliminary experiments proved that under the applied circumstances the freeze drying method did not damage any of these compounds.

\subsection{Chemical determinations}

1.5.1. Glycoalkaloid analysis. The analysis of glycoalkaloids was carried out by methods of TÖMÖSKÖZI-FARKAS and co-workers (2006).

1.5.2. Analysis of glutamine and asparagine content. Fifty milligrams of the lyophilised potato tuber sample was extracted with $1 \mathrm{ml}$ water for 30 minutes in an ultrasonic bath and then centrifuged for 10 minutes at $2000 \mathrm{~g}$. The supernatant was complemented to eluent 
composition with ammonium acetate and acetonitrile and was centrifuged for 10 minutes at $30000 \mathrm{~g}$. Five millilitres of the sample was injected into a Perkin Elmer Series 200 chromatograph. The components were separated on a $150 \times 2.1 \mathrm{~mm}, 5 \mathrm{~mm}$, ZIC-HILIC (Merck) column by gradient elution at a flow rate of $150 \mathrm{ml} \mathrm{min}{ }^{-1}$. Mobile phase component A was $20 \mathrm{mM}$ ammonium acetate ( $\mathrm{pH} 4.0$ ), component B was acetonitrile. From 0 to 8 minutes mobile phase B was kept at $80 \%$, from 8 to 20 minutes it was decreased to $40 \%$ then kept at this value for 3 minutes. The analytes were detected with a Perkin Elmer Sciex API 365 triple quadrupole mass spectrometer with an ESI ion source (Sciex, Toronto, Canada) in positive multiple reaction monitoring mode. Asparagine and glutamine were measured at the $m / z 133.1 \rightarrow m / z 73.9$ and $m / z 147.1 \rightarrow m / z 84.1$ transitions, respectively and quantitated using calibration standards prepared from an amino acid standard mix (Sigma-Aldrich).

1.5.3. Determination of nitrate and nitrite content. Measurements were carried out with the standard method of A.O.A.C. (2003).

\subsection{Statistics}

For the statistical analysis of the experimental data, Mann-Whitney test with Excel software was used.

\section{Results and discussion}

The results of statistical analysis of TGA indicated no direct relationship between the farming technology and the amount of glycoalkaloids (Table 1.). AsAmI and co-workers (2003) found that secondary metabolite production was more intensive for organic farming technology, because the biosynthesis of these components played a role in the plant defence system. On the basis of our three-year results, this conception could not be proved. Cultivar Rioja from organic production contained significantly higher amount of TGA in 2007 (Table 2), there was no difference in 2008, and the conventional circumstances resulted in a significantly higher TGA concentration in the third year (2009). In the case of Hópehely, there were no significant differences between TGA concentrations related to technology and years (Table 2.). This cultivar had the lowest and most stable level of TGA in all cases. However, the conventionally farmed White Lady contained significantly higher amount of TGA in 2007 and 2009. Considering the average TGA content of the same genotypes of all years, the results of the statistical analysis proved that the effect of year was the limiting factor. Furthermore, statistical differences were found between the cultivars in all years. In summary, the results showed that the season and the genotype had a greater effect than the farming technology on the amount of alkaloids. 
Table 1. Comparison of conventional $(\mathrm{C})$ and organic $(\mathrm{O})$ farming technology on anti-nutritive components of potato tubers of cv. White Lady, Rioja, and Hópehely in 2007-2009 using Mann-Whitney Probe

\begin{tabular}{lcccccccccc}
\hline Components & \multicolumn{3}{c}{2007} & \multicolumn{3}{c}{2008} & & 2009 & \\
\cline { 2 - 9 } & $\begin{array}{l}\text { White } \\
\text { Lady }\end{array}$ & Rioja & $\begin{array}{c}\text { Hó- } \\
\text { pehely }\end{array}$ & $\begin{array}{c}\text { White } \\
\text { Lady }\end{array}$ & Rioja & $\begin{array}{c}\text { Hó- } \\
\text { pehely }\end{array}$ & $\begin{array}{c}\text { White } \\
\text { Lady }\end{array}$ & Rioja & $\begin{array}{c}\text { Hó- } \\
\text { pehely }\end{array}$ \\
\hline $\begin{array}{l}\text { Asparagine } \\
\left(\text { mmol kg }^{-1}\right)\end{array}$ & $\mathrm{C}<\mathrm{O}$ & $\mathrm{C}>\mathrm{O}$ & $\mathrm{C}=\mathrm{O}$ & $\mathrm{C}=\mathrm{O}$ & $\mathrm{C}>\mathrm{O}$ & $\mathrm{C}>\mathrm{O}$ & $\mathrm{C}>\mathrm{O}$ & $\mathrm{C}>\mathrm{O}$ & $\mathrm{C}=\mathrm{O}$ \\
$\begin{array}{l}\text { Glutamine } \\
\left(\mathrm{mmol} \mathrm{kg}^{-1}\right)\end{array}$ & $\mathrm{C}<\mathrm{O}$ & $\mathrm{C}>\mathrm{O}$ & $\mathrm{C}=\mathrm{O}$ & $\mathrm{C}=\mathrm{O}$ & $\mathrm{C}=\mathrm{O}$ & $\mathrm{C}>\mathrm{O}$ & $\mathrm{C}>\mathrm{O}$ & $\mathrm{C}=\mathrm{O}$ & $\mathrm{C}=\mathrm{O}$ \\
$\begin{array}{l}\text { Nitrate } \\
\left(\mathrm{mg} \mathrm{kg}^{-1}\right)\end{array}$ & $\mathrm{C}>\mathrm{O}$ & $\mathrm{C}>\mathrm{O}$ & $\mathrm{C}>\mathrm{O}$ & $\mathrm{C}>\mathrm{O}$ & $\mathrm{C}>\mathrm{O}$ & $\mathrm{C}>\mathrm{O}$ & $\mathrm{C}>\mathrm{O}$ & $\mathrm{C}>\mathrm{O}$ & $\mathrm{C}=\mathrm{O}$ \\
$\begin{array}{l}\mathrm{TGA} \\
\left(\mathrm{mg} \mathrm{kg}^{-1} \text { raw potato) }\right.\end{array}$ & $\mathrm{C}>\mathrm{O}$ & $\mathrm{C}<\mathrm{O}$ & $\mathrm{C}=\mathrm{O}$ & $\mathrm{C}=\mathrm{O}$ & $\mathrm{C}=\mathrm{O}$ & $\mathrm{C}=\mathrm{O}$ & $\mathrm{C}>\mathrm{O}$ & $\mathrm{C}>\mathrm{O}$ & $\mathrm{C}=\mathrm{O}$ \\
\hline
\end{tabular}

$\mathrm{C}>\mathrm{O}$ conventionally grown potato tubers contained higher amount of the investigated component. $\mathrm{C}<\mathrm{O}$ organically grown potato tubers contained higher amount of the investigated component. $\mathrm{C}=\mathrm{O}$ No difference in data. (Data are significant at $\mathrm{P}<5 \%$.)

Table 2. Effect of conventional (C) and organic (O) farming technology on the TGA content of potato tubers of cv. White Lady, Rioja, and Hópehely in 2007-2009

\begin{tabular}{|c|c|c|c|c|c|c|c|}
\hline \multirow[t]{3}{*}{ Year } & \multirow{3}{*}{$\begin{array}{l}\text { Crop } \\
\text { system }\end{array}$} & \multicolumn{6}{|c|}{ TGA content of studied potato cultivars ( $\mathrm{mg} \mathrm{kg}^{-1}$ raw potato) } \\
\hline & & \multicolumn{2}{|c|}{ White Lady } & \multicolumn{2}{|c|}{ Hópehely } & \multicolumn{2}{|c|}{ Rioja } \\
\hline & & mean & $\mathrm{SD}$ & mean & $\mathrm{SD}$ & mean & SD \\
\hline \multirow[t]{2}{*}{2007} & $\mathrm{C}$ & 3.86 & 0.43 & 0.24 & 0.77 & 0.53 & 0.14 \\
\hline & $\mathrm{O}$ & 1.59 & 1.32 & 0.28 & 0.07 & 4.45 & 2.26 \\
\hline \multirow[t]{2}{*}{2008} & $\mathrm{C}$ & 15.10 & 5.63 & 0.00 & 0.00 & 1.94 & 2.65 \\
\hline & $\mathrm{O}$ & 28.09 & 17.25 & 0.00 & 0.00 & 0.47 & 0.51 \\
\hline \multirow[t]{2}{*}{2009} & $\mathrm{C}$ & 8.85 & 5.63 & 1.04 & 1.81 & 8.39 & 2.19 \\
\hline & $\mathrm{O}$ & 0.00 & 17.25 & 0.00 & 0.00 & 2.04 & 1.18 \\
\hline
\end{tabular}

Out of the nine cases ( 3 years $\times 3$ cultivars) the conventionally grown tubers had higher values in six cases for asparagine and in six cases for glutamine (Table 1). Although the detected alterations were proven to be statistically significant only in 3 cases for asparagine and 2 cases for glutamine, the tendency is clear. Nitrogen fertilisation during conventional farming has a positive effect on the amount of the examined amino acids. The data also 
revealed the genotype effect on the measured differences. Rioja had the highest asparagine content (62.4-122.0 mmol kg-1) under conventional farming in all the cases. On the contrary, White Lady had higher amino acid content in 4 cases under organic farming (3 times significant). This phenomenon can reflect the existence of differences in nitrogen reaction of the cultivars. The season itself had significant effect on asparagine and glutamine, because the lowest values in all three cultivars, under both farming technologies, were detected in 2007. This seasonal effect can be explained by the beneficial environmental circumstances for the mineralisation of nitrogen. Summarizing, the data of amino acids were affected primarily by the technology (Table 3 ).

Probably because of the fertilizers used, the nitrate content of tubers grown under conventional practice were higher than that of organically grown ones but the differences were not significant (Table 3 ). In case of the same cultivar and farming technology we could not detect significant effect of the season. However, nitrate content was primarily influenced by the genotype (Table 4). The results of HERENCIA and co-workers (2011) showed high data variability, because there were a large number of factors that could have effect on the nitrate content of crops. These results of high variability in nitrate content are in agreement with our data. The nitrite content of tubers was lower than $0.1 \mathrm{mg} \mathrm{kg}^{-1}$, except in a few cases, and there were no significant differences under the various circumstances (farming technology, cultivar or year, data are not shown).

Table 3. Effect of conventional (C) and organic (O) farming technology on the amount of asparagine and glutamine in potato tubers ( $\mathrm{mmol} \mathrm{kg} \mathrm{kg}^{-1}$ lyophilised potato) of cv. White Lady, Rioja, and Hópehely in 2007-2009

\begin{tabular}{|c|c|c|c|c|c|c|c|}
\hline \multirow[t]{3}{*}{ Year } & \multirow{3}{*}{$\begin{array}{l}\text { Crop } \\
\text { system }\end{array}$} & \multicolumn{6}{|c|}{ Asparagine content $\left(\mathrm{mmol} \mathrm{kg}^{-1}\right)$} \\
\hline & & \multicolumn{2}{|c|}{ White Lady } & \multicolumn{2}{|c|}{ Hópehely } & \multicolumn{2}{|c|}{ Rioja } \\
\hline & & mean & SD & mean & $\mathrm{SD}$ & mean & SD \\
\hline \multirow[t]{2}{*}{2007} & $\mathrm{C}$ & 35.4 & 1.6 & 43.7 & 7.8 & 62.4 & 3.7 \\
\hline & $\mathrm{O}$ & 47.3 & 1.6 & 45.8 & 1.4 & 43.9 & 4.6 \\
\hline \multirow[t]{2}{*}{2008} & $\mathrm{C}$ & 69.9 & 6.5 & 74.6 & 9.7 & 122 & 25.9 \\
\hline & $\mathrm{O}$ & 87.1 & 5.4 & 56.1 & 1.3 & 85.1 & 9 \\
\hline \multirow[t]{3}{*}{2009} & $\mathrm{C}$ & 90.9 & 11.3 & 78.1 & 29.3 & 113.3 & 16.5 \\
\hline & $\mathrm{O}$ & 54 & 4.2 & 52.2 & 13.4 & 83.7 & 6.3 \\
\hline & & \multicolumn{6}{|c|}{ Glutamine content $\left(\mathrm{mmol} \mathrm{kg}^{-1}\right)$} \\
\hline \multirow[t]{2}{*}{2007} & $\mathrm{C}$ & 16.8 & 1.4 & 22.1 & 4.5 & 28.3 & 2.3 \\
\hline & $\mathrm{O}$ & 33.9 & 2.6 & 22.7 & 0.9 & 13.3 & 1.3 \\
\hline \multirow[t]{2}{*}{2008} & $\mathrm{C}$ & 96.3 & 28.9 & 144.4 & 29.9 & 110.9 & 39.1 \\
\hline & $\mathrm{O}$ & 112.3 & 10.8 & 113.4 & 15.2 & 60.4 & 7.6 \\
\hline \multirow[t]{2}{*}{2009} & $\mathrm{C}$ & 74.6 & 9.8 & 70.2 & 23.2 & 47.5 & 5.4 \\
\hline & $\mathrm{O}$ & 40.1 & 1.4 & 46 & 11 & 39.1 & 7.2 \\
\hline
\end{tabular}


Table 4. Effect of conventional (C) and organic (O) farming technology on the nitrate content of potato tubers of cv. White Lady, Rioja, and Hópehely in 2007-2009

\begin{tabular}{llcccccc}
\hline \multirow{2}{*}{ Year } & Crop \\
& system & \multicolumn{5}{c}{ Nitrate content of studied potato cultivars $\left(\mathrm{mg} \mathrm{kg}^{-1}\right)$} \\
\cline { 3 - 7 } & & \multicolumn{2}{c}{ White Lady } & \multicolumn{2}{c}{ Hópehely } & \multicolumn{3}{c}{ Rioja } \\
& & mean & SD & mean & SD & mean & SD \\
\hline 2007 & C & 293.7 & 91.0 & 141.4 & 25.5 & 52.8 & 12.8 \\
& O & 79.5 & 46.2 & 77.8 & 41.4 & 26.0 & 5.3 \\
2008 & C & 198.0 & 16.5 & 192.7 & 24.7 & 68.3 & 8.4 \\
& O & 133.0 & 34.6 & 65.3 & 8.5 & 50.0 & 9.5 \\
2009 & C & 239.3 & 11.0 & 78.0 & 58.0 & 17.7 & 3.1 \\
& O & 90.0 & 30.3 & 81.3 & 43.0 & 11.7 & 1.2 \\
\hline
\end{tabular}

\section{Conclusions}

In our study, the absolute amount and changes of examined anti-nutritive components of potato tubers were influenced differently by the technology, genotype, and season in a complex manner. TGA content of tubers is under strong genetic control. Nitrate and consequently the asparagine and glutamine content can be increased by nitrogen fertilizers but its extent is very much dependent on the genotype and seasonal effects. Nitrite content is independent of farming technologies, while nitrate is dependent on the way of farming. The tendency is that the nitrate content in conventionally farmed potatoes is higher than in organically farmed potatoes.

The Hungarian potato cultivars bred by conventional breeding utilising resistance genes of wild species were proved to be appropriate for organic production without the risk of increased toxic TGA content. From the point of toxic nitrate content, Rioja is the most advised cultivar due to its low nitrate level irrespective of the used farming technology.

$*$

The financial support of the National Scientific Research Fund (OTKA 68706) and NFÜ (Burg009 project) is greatly appreciated.

\section{References}

Abreu, P., Relva, G., Matthew, S., Gomes, Z. \& Morais, Z. (2007): High-performance liquid chromatographic determination of glycoalkaloids in potatoes from conventional, integrated, and organic crop systems. $F d$ Control, 18, 40-44.

A.O.A.C. (2003): Official methods of analysis, Association of Official Analytical Chemists, $17^{\text {th }}$ ed., Determination of nitrite and nitrate content; Molecular absorption spectrometric method. No. 993.03.

Asami, D.K., Hong, Y.J., Barrett, D.M. \& Mitchell, A.E. (2003): Comparison of the total phenolic and ascorbic acid content of freeze-dried and air-dried marionberry, strawberry, and corn grown using conventional, organic, and sustainable agricultural practices. J. Agric.Fd Chem., 51, 1237-1241. 
Friedman, M. \& Levin, C.E. (2009): Chapter 6 - Analysis and biological activities of potato glycoalkaloids, calystegine alkaloids, phenolic compounds, and anthocyanins. -in: SingH, J. \& Kaur, L. (Eds) Advances in potato chemistry and technology. Elsevier Inc., Oxford, pp. 127-161.

Hajslova, J., Schulzova, V., Slanina, P., Janne, K., Hellenas, K.E. \& Andersson, C. (2005): Quality of organically and conventionally grown potatoes: four-year study of micronutrients, metals, secondary metabolites, enzymic browning and organoleptic properties. Fd Addit. Contam., 22, 514-534.

Herencia, J.F., Garcia-Galavis, P., Dorado, J.A. \& Maqueda, C. (2011): Comparison of nutritional quality of the crops grown in an organic and conventional fertilized soil. Sci. Hortic., 129, 882-888.

Matsurra-Endo, C., Ohara-Takada, A., Chuda, Y., Ono, H., Yada, H., Yoshida, M., Kobayashi, A., Tsuda, S., Takigawa, S., Noda, T., Yamauchi, H. \& Mori, M. (2006): Effects of storage temperature on the contents of sugars and free amino acids in tubers from different potato cultivars and acrylamide in chips. Biosci., Biotechnol. Biochem., 70, 1173-1180.

Rutkowska, G. (1999): Badanie zawartosci azotanow i azotynow w warzywach uprawianych konwencjonalnie i ekologicznie. (Nitrates and nitrites content in vegetables from conventional and ecological cultivations.) Przemysl Spozywczy, 53(6), 47-49.

Tömösközi-Farkas, R., Daood, H.G., Polgár, Zs. \& Hajós, Gy. (2006): Determination of glycoalkaloids in Hungarian potatoes by HPLC. Chromatographia, 63, 115-118.

WARMAN, P.R. \& HAVARD, K.A. (1998): Yield, vitamin and mineral contents of organically and conventionally grown potatoes and sweet corn. Agric. Ecosystems \& Environ., 68, 207-216.

Winter, C.K. \& Davis, S.F. (2006): Organic foods. J. Fd Sci., 71, R117-R124. 